\title{
Leading approaches to modernization of state financial control: a case of Ukraine
}

\author{
Natalia Novikova \\ Public Administration Department \\ Kyiv National University of Trade and Economics \\ Kioto str. 19, Kyiv, 02156 \\ Ukraine \\ e-mail: nazichka4021@gmail.com \\ Lydmyla Deshko \\ Public International Law Department \\ Kyiv National University of Trade and Economics \\ Kioto str. 19, Kyiv, 02156 \\ Ukraine \\ e-mail: deshkol@yahoo.com \\ Anna Gurzhii \\ Administrative, Financial and Information Law Department \\ Kyiv National University of Trade and Economics \\ Kioto str. 19, Kyiv, 02156 \\ Ukraine \\ e-mail: myknteu@gmail.com
}

\begin{abstract}
With the deepening of European integration, steady development of the national system of public finances and transition to international standards of state audit, become of particular importance the issues of the state financial control, as a key instrument for ensuring the legality, correctness and efficiency of accumulation and spending public funds. The development of this institute is an important indicator of society democratization and, at the same time, is a guarantee of transparency and publicity in public financial activities. Despite the significant progress in development of the state financial control in Ukraine, its overall efficiency remains low. At the current stage of development of the national public finances, there is an urgent need to improve the legal, organizational, economic and information grounds of state financial control. Achievement of this aim requires updating the existing legislative framework, creation of specialized web resources and other steps aimed at increasing the efficiency of control over the accumulation and spending public funds. The proposed steps are intended to promote the transition to international principles of state audit, development the mechanisms of public financial control, increase the effectiveness of control over the accumulation and spending of public funds.
\end{abstract}

\section{Introduction}

Constant increase of public financial activities, as well as permanent complication of financial and economic relations actualize the issues of public funds administering. At the same time, there is a high need to strengthen control over the use of public financial resources, correctness of budget calculations, public property administering, financial accounting and reporting. On the effectiveness of such control directly depend the level of legality and discipline in the public financial system, and, eventually, - total effectiveness of public financial and economic activity.

Despite the deeper involvement of independent public institutions into control over public finances, almost all world democracies give the leading role in this process to the state. And this is natural, since in modern conditions only the state is able to build a coherent system of controlling structures, conform their powers and coordinate their activities (Moyseyenko and Ryvak 2016; or Subačienè et al. 2018). Only the state has a sufficient resources and powers to implement comprehensive financial control at the levels of the community, the region and the whole country. Eventually only the state has material, organizational and other levers powerful enough to direct public financial activities into the course of national social-economic policy and ensuring of public interests (Narkunienè and Ulbinaite 2018). 
Not an exception from this case is modern Ukraine, where exactly the state bodies act as the main link in the mechanism of control over the accumulation and use of public funds (Mostenska 2015). During the period of independence, this link went through a difficult way of development. Being under inertia of Soviet governance system, suffering from half-baked reforms and from the absence of general strategy line, the Ukrainian system of state financial control for a long time functioned "in isolation" from global trends (Č́belková et al. 2015; Strielkowski et al. 2016; or Romanova et al. 2017). Until recently, it showed an example of a very unsuccessful organizational model, with the overage of disjointed elements, duplication of functions, and a purely fiscal orientation. In fact, this model could be called "the system" only conditionally, given the existence of some common aims. But actually, it represented an eclectic combination of a large number of organizational units, all of which functioned separately, without clear coordination and interaction with others (see e.g. Dikan et al. 2009; Pikhotskii 2014; or Slobodianik 2014).

At the same time, fast development of the state audit mechanisms, foundation of the State Audit Office and numerous legislation updates, actualized a wide range of problems that require urgent resolution. This can't be done on the basis of existing scientific researches, most of which do not take into account the specifics of new legal and organizational provisions on state financial control. All of the above stipulates the necessity of forming a set of scientific and practical recommendations aimed at increasing the efficiency of state financial control in modern Ukraine.

\section{Methodology}

The study based on a wide range of knowledge acquisitions. In particular, the dialectical method provided a comprehensive reviewing the questionы of state financial control at the junction of its legal, organizational and technical aspects. With the deductive method, the current state and perspectives of Ukrainian state audit are observed. The inductive method allowed to show systemic drawbacks of the national audit system on the example of certain legislative shortcomings and organizational problems in the sphere of public finances. The analytic methods used for observing scientific researches on state audit issues, as well as to study the peculiarities of Ukrainian financial legislation. Within the systematic approach, proposed the integral approach to solving organizational and legal issues of state financial control. Based on functional method, a number of suggestions, aimed on development the national audit system was been formulated.

\section{National audit system in the context of democratization}

However, since declaration of the commitment to democratic values and standards of public administration, the Ukraine initiated complex reform in the field of finances. Over the past years, Ukrainian government has made a number of important legal and organizational steps aimed at the implementation of world standards on state audit.

Particularly, in the national legislation was reflected a number of conceptual provisions of ISSAI 1 (the Lima Declaration) and ISSAI 2 (the Mexican Declaration) on the organization and implementation of external financial control (ISSAI 1997; ISSAI 2007).

The main bodies of state financial control were gradually redirected from the post-audit control to preaudit. If earlier their activity was limited to identifying and elimination the financial violations, today it is predominantly aimed at their prevention. For this purpose, the subjects of state financial control are given an increasing amount of control powers at the stages of budget planning and filling. More and more inspections have preventive character.

Parliamentary control body (Accounting Chamber) has finally started to control not only the expenditure but also the revenue part of the state budget (until recently, Ukraine was the only state among the 170 INTOSAI (International Organization of Supreme Audit Institutions) members, where the main control body had no control over the state budget planning). At the same time there was introduced the system of independent control over the financial activities of the Accounting Chamber as the main external auditor. According to current legislation, such control may be carried out either by a firm experienced in audit according to international standards (no more than 3 times in a row), or by the one of the leading members of INTOSAI.

The non-parliamentary branch of state financial control has been reorganized. From the double (government-presidential) subordination, it was transferred to complete government control. The number of controlling bodies has been reduced, their structure has been optimized. In 2016 was founded The State Audit Service of Ukraine, the central executive body, responsible for the formation and implementation of state policy in the field of financial control.

The entire legal framework for state financial control underwent several substantive changes. In particular, the law was adapted entitled "On Amendments to Article 98 of the Constitution of Ukraine on the Extension of the Constitutional Duties of the Accounting Chamber" (The Official Bulletin of Ukraine 2016). 
This represents a new version of the Law "On the Basic Principles of the Implementation of the State Financial Control in Ukraine"; - a new version of the Law "On the Accounting Chamber"; - Regulations on the State Audit Service of Ukraine etc. The law considerably expanded the possibilities of civil society to influence at the state activities in the field of financial control. In the structure of most control bodies, the Public Councils have been established to ensure the transparency of their rule-making and executive activities.

As a whole, it can be stated that the Ukrainian system of state financial control is developing in line with the general world trends, which involve the formation of the central (higher) level of external audit, multiparametric estimation of the economic efficiency of public administration, rational combination of preliminary, current and subsequent control, the implementation of international audit standards, wide public participation in solving the practical issues of state financial control, transparency and openness of control bodies with appropriate respect to state and commercial secrecy.

However, despite a number of positive trends, the national system of public financial control is still far from perfect. It is still difficult to call it a holistic and balanced one. According to the unanimous recognition of scientists and practitioners, the pace of its development is too slow, and its organizational, legal and methodological support is too poor to ensure maximum effective control over the accumulation and spending of public funds.

\section{Ukrainian state financial control: issues and challenges}

Problems affect virtually all levels and links of state financial control. Overlapping each other, they cross out existing achievements, reduce the effectiveness of control measures and hinder the development of state audit in general. The most sensitive of them are the next.

Despite the significant reduction in the number of state control bodies, that has taken place in Ukraine; their system remains very complicated and cumbersome (Gurzhii et al. 2018). Along with dozens of internal control services "inside" the authorities, it includes a large number of external control entities: the Accounting Chamber, the State Audit Service of Ukraine, the State Treasury Service of Ukraine, the State Fiscal Service of Ukraine, the National Bank of Ukraine, the State Commission on Securities and Stock Market, State Property Fund of Ukraine and others.

It should be noted that in most cases the creation of these entities proceeded in a disparate way. It took place without a clearly defined plan, and was not conducted in the framework of overall strategy of development of public financial control. As a result, the existing system of controlling entities is quite imbalanced. The limits of their competence are blurred. In some cases, there is a coincidence of control functions and cross-section of responsibilities. In practice, this leads to management conflicts, duplication of financial checks, and unsustainable use of resources.

As a whole, it should be noted that modern Ukraine faces negative situation, when, on the one hand, there is a significant number of controlling bodies, and on the other, there is no consistency and efficiency in their activities, which provokes increasing the number of financial violations (Basantsov 2008, p. 218).

Unlike most European countries, Ukraine has no Supreme Audit Institution, which would provide methodological support and coordination of activities of all other state controlling entities. At present, the Ukrainian system of state financial control covers two organizational subsystems: the Parliamentary (Accounting Chamber) and the government one, which includes a wide range of control bodies and units integrated into the structure of executive power.

In the absence of central coordination link, all these bodies often provide parallel and inconsistent activities. Such inconsistency take place both at the national and local levels. Often this leads to organizational "overlays", unreasonable follow-up audits, duplicating their results, issuing mutually different prescriptions in the same cases. In general, this state of affairs causes a different application of same provisions, ineffective use of material and technical resources and, consequently, a lack of noticeable progress in improving the efficiency of public financial control.

This situation demands the creation of strong coordinating center, which, on the one hand, would ensure the solution of administrative contradictions, and on the other hand, will consolidate and direct common efforts on the channel of constructive cooperation. The optimal way of achieving this goal is to accord the Accounting Chamber with the status of the supreme body of state financial control, as well as to give it appropriate coordinating, organizational and methodical functions.

It should be noted that the creation a higher body of state financial control follows from the Association Agreement between Ukraine and the EU, which imposes on Ukraine the responsibility for ensuring the development of public internal control and external audit, on the basis of international standards and fundamental principles of accountability, transparency, economy, efficiency and effectiveness (Association Agreement 2014). 
The Ukrainian system of state financial control is functioning without basic law defining the key concepts in audit sphere, assigning tasks, functions and powers between the audit services, regulating relations between auditors and audited entities, determining the responsibility and independence of audit institutions and their executives (Vasilik 2002, p. 114). The Law of Ukraine "On the Basic Principles of the Implementation of the State Financial Control in Ukraine" defines the status of only the one controlling structure - the State Audit Office of Ukraine - the central executive body, responsible for implementation of state policy of financial control (The Official Bulletin of Ukraine 1993).

The activities of all the other audit services are regulated by a wide range of disparate regulatory acts, which are characterized by poor consistency, numerous collisions and duplications.

Imperfect legal regulation substantially narrows the limits of public financial control. In particular, there is no legislative field for external audit activities carrying out by the State Audit Office of Ukraine. In its turn, the absence of the necessary legal mechanisms makes impossible for the State Audit Office of Ukraine to audit EU funds and grants, state (regional) programs, investment projects, internal audit system and a number of other aspects of public activity related to filling and using of public funds.

In our opinion, among the priorities of development of the state financial control in Ukraine should be the utmost clear regulation of the relationships between audit services (special attention should be paid to relations concerning external audit of their financial activities).

Despite the fact that the organizational structure of the national system of financial control in general meets the principles of the Lima Declaration, in its ideology, it has preserved and continues to use Soviet traditions, inheriting all the disadvantages of static system. Today, it is aimed primarily at assessing compliance with the law and the correct use of public funds. Instead, socio-political results of financial activities (i.e., social effectiveness of public financial management) are analyzed only fragmentarily (Lisiak 2015).

Ukrainian legislation imposes on the Accounting Chamber the power to carry out not only a financial audit, but also an audit of efficiency. However, in this case, the basis for the calculation of efficiency is based on purely legal, organizational and economic criteria. For instance, according the Law of Ukraine "On the Accounting Chamber", the audit of efficiency provides for an assessment: the timeliness and completeness of budget revenues, productivity, efficiency, economy of use of budget funds by their managers and recipients, legality, timeliness and completeness of making management decisions by participants of the budget process, the state of internal control of budget managers funds (Official Bulletin of Ukraine 2015)

As it can be seen, in this case that it is not so much about audit of efficiency (in terms of achieved social results), so much about checking the legality, correctness and efficiency of administering public finances by individual entities. At the same time, clear criteria for measuring effectiveness have not been defined yet. As well, were not defined the legal consequences of the auditors' conclusion about poor social outcomes of public financial activities. This issue is especially acute in cases where financial activity of public administration is economically productive, but socially ineffective.

In addition, if the Lima Declaration (Part 2, Article 4) provides the audit of the effectiveness of entire administrative system, the current Ukrainian legislation reduces it to the level of separate bodies (participants of budget process, administrators and recipients of budget funds, etc.). As a result, the comprehensive assessment of public financial management currently is not provided, which, in turn, hinders measuring the effectiveness of national financial policy.

In order to solve this issue, it is advisable to follow the example of Sweden where audit of efficiency carried out at the regional and national levels, as well as at the level of separate entities. The two main efficiency indicators - economic performance and social performance - are measured on wide range of criteria (in particular, the analysis of social performance implies the assessment of more than 50 different criteria). At the same time, those aspects of public financial activity, which were found to be economically effective (profitable) but ineffective socially (i.e., did not ensure the achievement of socio-political aims), can't be approved (Strekal 2016, p. 31).

Despite the expansion of the powers of the Accounting Chamber, as the independent body of external audit), its activities at the local level are still limited. As of 01.01.2018, in Ukraine there are only seven territorial departments of the Accounting Chamber. This, in particular, departments in the cities: Kiev, Dnipro, Donetsk, L'viv, Odessa, Kharkiv and Vinnitsa. Most of them extend their activities to 2 or 3 regions. The departments in Vinnitsa and L'viv covers the territory of 4-6 regions at once. At the same time, most of them consist of only 3 subdivisions with comparatively small staff. Thus, today neither the structure, nor the personnel of these subdivisions is able to fully perform their audit functions.

The aforementioned shift in the development of state financial control from post to pre-audit proceeds too slowly. The majority of the audit services received legal powers to carry out previous and current financial audits, but at the same time were not provided with the methods, adapted to the progress of the sciences and techniques relating to financial management. As a result, they continue to favor the post-audit measures. The measures of preliminary and ongoing audit are carried out only occasionally, and their influence on public financial activities is almost imperceptible. 
A strong factor in the negative pressure on the efficiency of public financial control is the low level of responsibility and accountability of controlled entities (primarily, public authorities and business entities of the state sector of the economy). Public authorities do not always show a high level of consciousness and responsibility, ignoring the auditors' recommendations. As for mandatory regulations, the responsibility for their violations is too soft to ensure effective influence on the offenders.

For example, according to Art. 164-2 Code of Ukraine on administrative offences (CUAO), which establishes responsibility for concealing unproductive costs and losses, making false data to the financial statements, failing to provide financial statements, obstructing audits and inspections and other similar violations, provides for a fine of 8 to 15 non-taxable minimum incomes of citizens (Bulletin of the Supreme Council of the Ukrainian SSR 1984). As it clearly seen, this amount of fine is minuscule (by the beginning of 2018, this fine is equivalent to 4.5-8 Euros.) compared with the possible unlawful gain from financial abuses. In the light of this, some executives quite deliberately, and worst of all, very easily violate the requirements of financial discipline.

Despite the fact that in recent years Ukraine has taken a number of important steps to implement the financial control standards developed by the International Organization of Supreme Audit Institutions (INTOSAI), the European Organization of Supreme Audit Institutions (EUROSAI), the Institute of Internal Auditors (IIA) and the International Federation Accountants (IFAC), this process is far from complete. In particular, the legislation of Ukraine still did not reflect the INTOSAI directives regarding: 1) the creation of Supreme Audit Institution (SAI) and the constitutional determination of its status; 2) granting SAI the right of legislative initiative; 3) coordination of the state audit services; 4) improving audit of missions abroad (today audit is carried out only in diplomatic establishments of Ukraine); 5) audit of legality (conformity) for the state sector of the economy; 6) creation of an independent system for monitoring the implementation of the recommendations of the SAI etc. (Aleksandrovich 2015, p. 203)

An important issue for building a unified system of state financial control is its informational and software support. To date, in Ukraine there is no information link in the system of state financial control. Available information resources are dispersed among different audit services and are hardly compatible. Besides, make themselves felt problems of non-compliance of information resources to modern requirements for audit services; the lack of unified classification and coding system; the absence of regulatory and legal support; methodological inconsistency of data exchange processes.

At present moment the development of electronic information exchange between audit services and other executive authorities is slowed down due to usage of various not adapted software products and the existence of numerous interagency barriers at both central and local levels.

In the light of Ukraine's movement toward European integration, raises the issue of transition of its financial control system to European standards of audit. After all, the implementation of the EU-Ukraine Association Agreement on public finance management depends on its solution. At the same time, it is necessary to bear in mind the fundamental clause of INTOSAI (Art. 18) regarding the implementation in national legislation depends on the conditions and requirements of each country. Of course, this also applies to Ukrainian realities, which should be taken into account when implementing the appropriate legal and organizational measures.

\section{Outcomes and discussion}

One can see that a rather tangible problem in Ukrainian legislation is the absence of conceptual delineation between the systems of external and internal public audit. Contrary to the Lima Declaration, which clearly distinguishes external audit (as the activity of control services which are not part of the organizational structure of the institutions to be audited) and internal audit (as the activity of control services established within government departments and institutions), the Ukrainian legislation is officially recognizes only one subject of external audit - the parliamentary control body (Accounting Chamber). The status of the remaining controlling entities that carry out financial audits at the local level remains uncertain in this respect.

This conditioned the formation in the national law doctrine of a very specific paradigm of the delineation between external and internal financial control, where external audit means the only parliamentary control, and internal - means any forms of control activities carried out within the system of executive power, regardless of subordination between audit services and audited institutions. In fact, it is customary to assign internal control all forms of audit carried out by the bodies of executive power. In fact, it is customary for Ukraine to refer to internal control all forms of audit carried out by executive authorities

Typical for Ukrainian science and practice are the statements, such as: "the Government through its control services must ensure that the preliminary, current and post audit of public finances. Such control by its nature is internal (governmental) control” (Dmitrenko 2010, p. 85) or “... external control can't be carried out 
by executive entities" (Pikhotskii 2014). By external control activities should be monitored both the entire branch of executive power and its internal control system (Pikhotskii 2014, p. 114)".

This situation essentially influences on the development of public financial control in Ukraine, which "deviates" from pan-European tendencies. And this, in turn, creates significant obstacles to the implementation of the best models of audit in national administrative practice.

\section{Conclusions}

Summarizing all of the above, one has to state the complexity of the problems related to state financial control. They are conditioned by the wide range of factors (legal, organizational etc.) and are given at different levels of public administration: national, sectoral, regional. They are inextricably linked, and thus can't be solved separately, through disparate measures.

The situation requires the use of an integrated approach that covers all aspects of public financial control, implies optimization of all its components and, as a final result, - ensures maximum transparency and efficiency of public financial activities. The first steps in this direction should be the following.

In the field of legislative regulation, the following steps should be made: First of all, constitutional enshrinement of Accounting Chamber as a higher body in the system of state financial control, recognition its autonomy in relations with Parliament, granting it the right of legislative initiative, guaranteeing its independence from interference by the authorities, as well as guaranteeing the independence of its personnel. Second, adoption of the Law on Public Financial Control, based on the principles of INTOSAI Lima and Mexico Declarations, which would make clear distinction between external and internal audit systems, determine the status of all audit entities, define areas of their competence and responsibility. Third, thorough revision of the legislation on state financial control for consistency, coherence and compliance with international treaties of Ukraine. Fourth, criminalization of offenses connected with non-fulfillment of audit prescriptions and providing auditors with knowingly false information. In turn, such a step involves a significant increase in fines imposed on the offender, as well as the possibility of applying such criminal measures as arrest, restriction of freedom, prohibition to hold office, etc.

In the field of organizational support, the following steps should be taken care of: First of all, reduction the number of external audit entities, strict definition of their competence and areas of responsibility, elimination of parallelisms in their work. Second, establishing of Accounting Chamber regional offices in all regions of Ukraine. Ensuring their autonomy and independence. Proving their personnel, infrastructure and logistical resources to the indicators determined by the best world practices. Third, assigning to the Accounting Chamber to carry out the audit of all state organizations abroad (now it can audit only foreign diplomatic institutions). Fourth, empowering the Accounting Chamber to audit the efficiency of public financial activities. Audit of efficiency should be carried out at the regional and national levels, as well as at the level of separate entities. Fifth, empowering the State Audit Office of Ukraine to audit EU funds and grants, state (regional) programs, investment projects, internal control system and several aspects of public financial activity.

In stuffing, the following measures should be conducted: First, an increase the licensed number of specialists on financial control enrolled to educational institutions with sufficient potential (personnel, resource etc.) and experience. Second, implementation of professional and educational standards for obtaining bachelor's and master's degrees on the specialization "Financial Control". Third, maximum involvement of auditorspractitioners into all stages of educational process: from the development of educational programs to the final certification. Fourth, setting up of regular internal designed to improve auditors' competences and qualification.

When it comes to the field of methodological support, the following measures should be undertaken: First, completing the process of unification of the terminology of financial audit in accordance with INTOSAI standards. Second, implementation the best European methods for carrying out financial audit, audit of efficiency, expertise, analysis and other control measures. Third, determination of the criteria for economic and social efficiency of public financial activity, recognizing the criteria of social efficiency as a decisive factor in their evaluation. Financial activities which are economically effective (profitable) but ineffective socially (i.e., did not ensure the achievement of socio-political aims), can't be approved.

In the sphere of information and communication, the following steps should be made: First, development of the Information-Analytical System of State Financial Control (IASSFC) which would ensure the access of controlling entities of all levels to: - the regulatory framework for state financial control; - information on planned, provided and implemented control measures (incl. information about objects, subjects, terms and general results of inspections); - modern methods of financial audit and audit of efficiency. Second, granting the IASSFC access to all state registers and databases in the field of accumulation and use of public funds. Third, providing automatic informational interaction between IASSFC and existing electronic informational systems on public funds administration ("Single Web Portal for the Use of Public Funds", "Open Budget", "Public Budget", 
etc.). Fourth, development of unified software for automatic audit operations. Finally, implementing the integrated system of electronic interaction and informational exchange in the system of state financial control.

Apart from the steps, a wide range of legislative, organizational, technical and other measures aimed at building an integral system of state financial control is strongly needed. But anyway, all these measures can be most successful only within the framework of world audit standards. Implementation of these standards should be declared a main direction of the state financial policy and, to this end, it must be clearly defined in current legislation, strategic acts and political decisions. Then and only then administering of public finances will progress steadily, and only then, it will meet the high demands of the present and future.

\section{References}

Aleksandrovich O (2015) Modernization of the system of state financial control of Ukraine in the context of implementation of world experience. Actual Problems of Public Administration 2:192-202

Association Agreement (2014) Association Agreement between the European Union and the European Atomic Energy Community and their Member States, of the one part, and Ukraine, of the other part of June 27, 2014, The Official Bulletin of Ukraine, 75(1), Art. 2125.

Basantsov I (2008) Development of State Financial Control under Conditions of Market Economy in Ukraine. Irpen: NUTS.

Bulletin of the Supreme Council of the Ukrainian SSR (1984) Code of Ukraine on Administrative Offenses of December 7, 984 No. 8073-X. Bulletin of the Supreme Council of the Ukrainian SSR, 1984, No.15 (supplement), Art. 1122.

Č́aelková I, Abrhám J, Strielkowski W (2015) Factors influencing job satisfaction in post-transition economies: the case of the Czech Republic. International Journal of Occupational Safety and Ergonomics 21(4):448-456. doi: 10.1080/10803548.2015.1073007

Dikan L, Holub Y, Syniuhina N (2009) Financial Control: Theory and Methodology, $1^{\text {st }}$ edn. (Kharkiv: KhNEU, 2009), $250 \mathrm{p}$.

Dmitrenko G (2010) Organization and Implementation of State Control in Ukraine, $1^{\text {st }}$ edn. (Kyiv: National Academy for Public Administration under the President of Ukraine, 2010), 110 p.

Gurzhii T, Gurzhii A, Seliukov V (2018) Public Administration of Personal Data Protection in Modern Ukraine. Politické vedy 21(2):138-158. doi: 10.24040/politickevedy.2018.21.2.138-158

ISSAI 1 (1977) The Lima Declaration. The official site of The International Organisation of Supreme Audit Institutions (INTOSAI). http://www.intosai.org/issai-executive-summaries/view/article/issai-1-the-limadeclaration.html. Accessed 19 Aug 2018

ISSAI 10 (2007) The Mexico Declaration on SAI Independence. The official site of The International Organisation of Supreme Audit Institutions (INTOSAI). http://www.intosai.org/issai-executivesummaries/view/article/issai-10-the-mexico-declaration-on-sai-independence.html. Accessed 20 Aug 2018

Lisiak L (2015) Development of state financial control in Ukraine. Economic Herald of the University 26(1):200-206

Mostenska T (2015) Informal market as a result of shadow economy. Czech Journal of Social Sciences, Business and Economics 4(2):23-29. doi: 10.24984/cjssbe.2015.4.2.3

Moyseyenko I, Ryvak N (2016) Indirect taxes in the mechanism of state regulation. International Economics Letters 5(2):63-71. doi: 10.24984/iel.2016.5.2.4

Narkunienè J, Ulbinaitė A (2018) Comparative analysis of company performance evaluation methods. Entrepreneurship and Sustainability Issues 6(1):125-138. doi:10.9770/jesi.2018.6.1(10)

Official Bulletin of Ukraine (2012) The Law of Ukraine of December 16, 2012, No. 5463-VI "On Amendments to Certain Legislative Acts of Ukraine on the Activities of the Ministry of Finance of Ukraine, the Ministry of Economic Development and Trade of Ukraine, and other central executive bodies whose activities are directed and coordinated through the relevant ministers" (edited as of February 10, 2016), No. 93, Art. 3767. 
Official Bulletin of Ukraine (2015) The Law of Ukraine of July 2, 2015, No.576-VIII "On the Accounting Chamber" (edited as of January 5, 2017), No. 63, Art. 2074.

Pikhotskii V, The system of state financial control in Ukraine: conceptual foundations of theory and practice, $1^{\text {st }}$ edn. (Lviv: Lviv Polytechnic, 2014), 128 p.

Romanova O, Korovin G, Kuzmin E (2017) Analysis of the Development Prospects for the High-Tech Sector of the Economy in the Context of New Industrialization. Espacios 38(59): 25.

Slobodianik Y, Formation of the system of state audit in Ukraine, $1^{\text {st }}$ edn. (Sumy: FOP "Natalukha A.S.", 2014), $220 \mathrm{p}$.

Strekal O (2016) The Lima Declaration and its Impact on the Formation of Modern Models of State Financial Control in EU Countries. Effective Economics 9(31):1-10.

Strielkowski W, Tumanyan Y, Kalyugina S (2016) Labour Market Inclusion of International Protection Applicants and Beneficiaries. Economics \& Sociology 9(2):293-302. doi: 10.14254/2071-789X.2016/9-2/20

Subačienė R, Alver L, Brūna I, Hladika M, Mokošová D, Molín J (2018) Evaluation of accounting regulation evolution in selected countries. Entrepreneurship and Sustainability Issues 6(1):139-175. doi: 10.9770/jesi.2018.6.1(11)

The Official Bulletin of Ukraine (1993) The Law of Ukraine of January 26, 1993, No. 2939-XII "On the Basic Principles of the Implementation of the State Financial Control in Ukraine”, No. 13, Art. 110.

The Official Bulletin of Ukraine (2013) The Law of Ukraine of September 19, 2013, No. 586-VII "On Amendments to Article 98 of the Constitution of Ukraine on the Extension of the Constitutional Duties of the Accounting Chamber", No. 78, Art. 2895.

The Official Bulletin of Ukraine (2016) The Decree of the Cabinet of Ministers of Ukraine of February 3, 2016, No. 43 "On Approval of the Regulation on the State Audit Office of Ukraine", No. 12, Art. 506.

Vasilik O, Theory of Finances, $1^{\text {st }}$ edn. (Kyiv: Vydavnitstvo "NIOS”, 2002), 120 p. 